Article

\title{
Soil Heat Flux Modeling Using Artificial Neural Networks and Multispectral Airborne Remote Sensing Imagery
}

\author{
Dario J. Canelón ${ }^{1}$ and José L. Chávez ${ }^{2, *}$ \\ 1 Department of Bioproducts and Biosystems Engineering, University of Minnesota, \\ 1390 Eckles Ave., Saint Paul, MN 55108, USA; E-Mail: canel008@umn.edu \\ 2 Department of Civil and Environmental Engineering, Colorado State University, \\ 1372 Campus Delivery, Fort Collins, CO 80523, USA
}

* Author to whom correspondence should be addressed; E-Mail: Jose.Chavez@colostate.edu; Tel.: +1-970-491-6095; Fax: +1-970-491-7727.

Received: 16 May 2011; in revised form: 24 July 2011 / Accepted: 27 July 2011 /

Published: 2 August 2011

\begin{abstract}
The estimation of spatially distributed crop water use or evapotranspiration (ET) can be achieved using the energy balance for land surface algorithm and multispectral imagery obtained from remote sensing sensors mounted on air- or space-borne platforms. In the energy balance model, net radiation $\left(R_{n}\right)$ is well estimated using remote sensing; however, the estimation of soil heat flux $(\mathrm{G})$ has had mixed results. Therefore, there is the need to improve the model to estimate soil heat flux and thus improve the efficiency of the energy balance method based on remote sensing inputs. In this study, modeling of airborne remote sensing-based soil heat flux was performed using Artificial Neural Networks (ANN). Soil heat flux was modeled using selected measured data from soybean and corn crop covers in Central Iowa, U.S.A. where measured values were obtained with soil heat flux plate sensors. Results in the modeling of $G$ indicated that the combination $R_{n}$ with air temperature $\left(\mathrm{T}_{\text {air }}\right)$ and crop height $\left(\mathrm{h}_{\mathrm{c}}\right)$ better reproduced measured values when three independent variables were considered. The combination of $\mathrm{R}_{\mathrm{n}}$ with leaf area index (LAI) from remote sensing, and $R_{n}$ with surface aerodynamic resistance $\left(r_{a h}\right)$ yielded relative larger overall correlation coefficient values when two independent variables were included using ANN. In addition, air temperature $\left(\mathrm{T}_{\text {air }}\right)$ may be a key variable in the modeling of $\mathrm{G}$ as suggested by the ANN application ( $r$ of 0.83 ). Therefore, it is suggested that $R_{n}, L A I, r_{a h}$ and $h_{c}$ and potentially $T_{\text {air }}$ be considered in future modeling studies of $\mathrm{G}$.
\end{abstract}


Keywords: artificial neural networks; soil heat flux; aerial remote sensing; evapotranspiration; surface energy balance

\section{Introduction}

There are several available models to spatially estimate the surface energy balance components from remote sensing [1]. In particular, the soil heat flux (G) models have only been applied, with different degrees of success, in conditions similar to those in which they were developed (e.g., a given vegetation type, soil background, and environmental conditions) [2,3]. There is a need to further understand the variables that explain $G$ for a range of surface crops and for different environmental and climatic conditions. Net radiation $\left(\mathrm{R}_{\mathrm{n}}\right)$ estimates from remote sensing are fairly accurate according to Neale et al. [4], but soil and sensible heat flux $(\mathrm{H})$ estimates need more research $[5,6]$. In the case of G, Chávez [5] evaluated several G models for remote sensing applications, found in the literature, over corn and soybean fields. In that study, the models were a function of vegetation indices and a budget of short and long wave radiation. Results of that study indicated that the tested G models under predicted measured $G$ with mean bias errors and root mean square errors (MBE \pm RMSE) varying from $-5.4 \pm 25$ to $-47 \pm 44.3 \mathrm{~W} \mathrm{~m}^{-2}$ (i.e., an error of approximately $30 \%$ ) and therefore showing that there was a need to further infer on other surface or climatic variables that could help improve the modeling of soil heat flux for remote sensing purposes. In another study over cotton fields [6], it was found that a $\mathrm{G}$ model that incorporated surface thermal temperature, retrieved using a remote sensing sensor, performed better $-9.9 \pm 20 \mathrm{~W} \mathrm{ma}^{-2}$ (MBE \pm RMSE) than simply using vegetation indices and a budget of short and long wave radiation. Thus, there is a need to identify appropriate variables that would improve the prediction of G. Improvement in the estimation of the energy balance variables is needed as latent heat flux (LE) is usually obtained as a residual from the energy balance equation $\left(\mathrm{LE}=\mathrm{R}_{\mathrm{n}}-\mathrm{G}-\mathrm{H}\right)$. Estimation errors in terms of the energy balance equation (i.e., $\mathrm{R}_{\mathrm{n}}, \mathrm{G}$, and $\mathrm{H}$ ) would propagate and affect the accurate estimation of LE or distributed vegetation water use.

The soil heat flux is the energy that passes through the surface of the soil (in or out). During the day $\mathrm{G}$ flows into the soil (positive flux) adding energy to it and thus increasing its temperature. However, during the night time the heat stored during the day in the soil is released to the atmosphere (negative flux) cooling the soil down. Since the incident solar and atmospheric radiation reaching the soil surface is reduced by the amount of the vegetation biomass presence then several authors [7-9] have suggested relating $G$ to $R_{n}$ and to a vegetation index (i.e., an index like NIR/RED, NDVI, SAVI, OSAVI, etc.). NIR is surface reflectance in the Near Infra-red band of the electro-magnetic spectrum, RED is surface reflectance in the red band, NDVI is the normalized difference vegetation index that uses reflectance values in the RED and NIR bands, SAVI is the soil adjusted vegetation index, and OSAVI is the optimized soil adjusted vegetation index. OSAVI, SAVI and NDVI use surface reflectance in the RED and NIR bands and are used to quantify the amount of vegetation in the land surface. Some examples of the use of vegetation indices (VI), in an effort to relate linearly $\mathrm{G}$ to $\mathrm{R}_{\mathrm{n}}$, include Clothier et al. [7] who used the NIR/RED reflectance ratio for an alfalfa surface cover and Kustas and Daughtry [10] who used the NDVI index. Other researchers $[2,3,11]$ used an exponential relationship to relate $G$ to 
NDVI and $R_{n}$. Additional methodologies to obtain $G$ from remote sensing inputs suggested just a constant function of $R_{n}[8,9,12]$. However, $G$ models can estimate soil heat flux with a wide degree of uncertainty depending on the vegetation and environmental conditions considered and the method used in their development $[2,3,5]$. As shown above, developers of $\mathrm{G}$ models have been limited to a few numbers of variables (i.e., net radiation and VI) and statistical methods (simple linear regressions and exponential fits of $\mathrm{G}$ to $\mathrm{R}_{\mathrm{n}}$ and VI) thus the resulting $\mathrm{G}$ models, of Clothier et al. [7] and Kustas and Daughtry [10] did not present a very large coefficient of determination $\left(\mathrm{R}^{2}\right)$. Their coefficients of determination were $0.74-0.76$ for studies involving VI (NIR/RED) over alfalfa, cotton, and bare soil. Perhaps some variables other than $\mathrm{R}_{\mathrm{n}}$ and VI (e.g., plant parameters, surface and atmospheric conditions) could improve $\mathrm{G}$ modeling and increase the coefficient of determination.

As an alternative, Artificial Neural Networks (ANNs) represent one of several techniques derived from the artificial intelligence (AI) field of knowledge. They are computational models based on the behavior of biological neural networks, and can be adjusted (trained) so that a particular input leads to a specified target output. ANN can be employed as a data analysis tool, instead of multiple regression analysis (MRA), for forecasting and prediction based on historical data. ANN is most likely to be superior to other techniques under certain conditions, such as fuzzy inputs, subtle patterns, unpredictable non-linear data, and chaotic data (in the mathematical sense) [13]. ANN techniques have been applied to different hydrological processes and were able to model them more accurately by integrating a large number of variables and boundary conditions. For instance, ANN have been successfully used to predict long-range precipitation [14], groundwater levels [15], multi-ecosystems carbon flux [16], nitrogen and ammonia removal [17], and evapotranspiration [18-20].

In a particular study conducted in semi-arid regions [21], reference evapotranspiration values predicted using ANN showed better agreement with observed values than those obtained with the well-known Hargreaves' method.

Therefore, in this study, ANNs were used to identify the variables that contributed to the flux of heat into the soil and model the process considering multispectral remote sensing inputs.

\section{Materials and Methods}

Data were acquired near the city of Ames, Iowa at the Walnut Creek watershed over an area of approximately $12 \times 22 \mathrm{~km}$. The data acquisition in Iowa was part of the 2002 soil moisture and water cycle field experiments conducted in support to the Aqua Advanced Microwave Scanning Radiometer (AMSR), NASA's Global Water and Energy Cycle Program, and future satellite missions for Terrestrial Hydrology. Main elements of the experiment were validation of AMSR brightness temperature and soil moisture retrievals, extension of instrument observations and algorithms to more challenging vegetation conditions, integration of land surface and boundary layer measurements, and the evaluation of new instrument technologies for soil moisture remote sensing. The Soil Moisture Experiments in 2002 (SMEX02) and the Soil Moisture-Atmosphere Coupling Experiment (SMACEX02) were conducted in Iowa over a one-month period between mid-June and mid-July. An overview article provides background and including rationale for study, site description, experimental design, hydro-meteorological conditions and summary of results by Kustas et al. [22]. 


\subsection{Remote Sensing Data}

Multispectral digital imagery were acquired over soybean and corn fields in the study area using the USU airborne digital remote sensing system [23,24]. The system comprised four cameras: (a) three Kodak Megaplus digital frame cameras, for short wave bands, with interference filters centered in the green $(0.545-0.560 \mu \mathrm{m})$, red $(0.665-0.680 \mu \mathrm{m})$ and NIR $(0.795-0.809 \mu \mathrm{m})$ portions of the electro-magnetic spectrum; (b) one Inframetrics 760 thermal infrared scanner $(8-12 \mu \mathrm{m})$ camera that provided surface radiometric temperature images. High-resolution multispectral imagery was acquired on several different days during the intensive sampling period of the SMACEX experiment during the months of June and July 2002. Three major flight dates were 16 June (DOY 167), 1 July (DOY 182) and July 8 (DOY 189), planned to coincide with Landsat 5 Thematic Mapper overpasses. These regional flights covered the entire study area $(12 \times 22 \mathrm{~km})$ at a nominal pixel resolution of $1.5 \mathrm{~m}$ from an altitude of approximately 3,350 $\mathrm{m}$ (11,000 feet above ground level, a.g.l.). Imagery was also acquired on the same days from a lower altitude of 2,100 m (7,000 ft a.g.1.) over selected fields containing energy balance stations (flux flights), resulting in a short wave bands pixel resolution of $1 \mathrm{~m}$. The short wave camera lens F-stop settings were f5.6 for the green and red bands and f8.0 for the NIR. The shutter speed settings were $10 \mathrm{~ms}$ for the first flights (DOY 167 and 182) and $15 \mathrm{~ms}$ for the DOY 189 flight. The sky conditions for all flight time periods were mostly free of clouds. Considerable atmospheric interference due to smoke was present during the acquisition period on DOY 189. The prevailing wind direction during all the flights was from the south to southwest.

The short-wave images were corrected for lens vignetting effects and geometric radial distortions in procedures similar to those described in the literature $[23,25]$. The individual spectral images were registered into 3-band images and rectified to a 1:24,000 digital orthophotoquad base map. The individual rectified images were then mosaicked along the flight lines to form image strips that in turn were stitched together to form a mosaic of the entire study area, for each regional flight.

The digital numbers of the rectified multispectral image strips were converted to radiance using a system calibration method [23]. These radiances were divided by the incoming solar irradiance obtained from radiance measured, with an Exotech radiometer, concurrently over a barium sulfate standard reflectance panel with known bi-directional properties [26] to obtain surface spectral reflectance. The reflectance imagery calibration was verified using ground-truth reflectance values obtained with a similar Exotech ground 'roaming' radiometer. Surface reflectance readings performed with the roaming Exotech radiometer were carefully related to geographic coordinate readings obtained with a global positioning system (GPS) device in order to properly compare surface reflectance measured on the ground (roaming radiometer) and by the airborne system (digital cameras) at the exact same areas or locations.

The thermal infrared imagery was mosaicked along the flight lines and rectified to the high-resolution 3-band image mosaic described above. The digital numbers were transformed into apparent (at sensor) temperature values using the system calibration bar at the bottom of each image. The images were corrected for atmospheric and surface emissivity effects using MODTRAN v3.0 [27], an Atmospheric Radiative Transfer Model (software) following published recommendations and procedures [28,29]. This correction resulted in at-surface radiometric temperatures. Radiosonde 
observations acquired at the Lidar site during the over flights were used to obtain the necessary input data to the MODTRAN model.

All image processing was conducted using the ERDAS Imagine software. Spatial distribution of the fluxes was obtained using the high resolution calibrated and geo-referenced imagery as inputs along with ground measured meteorological data at the towers, by programming the appropriate equations within ERDAS Imagine model maker.

Surface reflectance images were used to develop vegetation indices, percent cover, surface albedo, leaf area index, and crop height. Remote sensed surface radiometric temperature and albedo images along with weather data (air temperature, relative humidity, and barometric pressure) were used to obtain net radiation; as described in [30].

\subsection{Soil Heat Flux Plate Sensor Data}

Soil heat flux plates (model HFT3, REBS, Seattle, WA, USA), four at each Eddy Covariance (EC) site of monitoring stations, were used to measure soil heat flux $(\mathrm{G})$. In addition, the stations were equipped with two thermal infrared thermometers (IRT) from Apogee (Logan, UT, USA). One of these instruments was located below the canopy measuring an "effective" soil brightness temperature and the other was located on the tower viewing the canopy from nadir, nominally at $5 \mathrm{~m}$ a.g.l. for the corn sites and $3 \mathrm{~m}$ a.g.l. for the soybean sites. Soil heat flux was measured at each station with four soil heat flux plates distributed across the corn and soybean rows and installed at an $8 \mathrm{~cm}$ depth along with soil temperature thermocouples placed within the topsoil layer and soil moisture sensors to account for heat storage above the plates.

There were a total of 11 different EC flux stations in nine different corn and soybean fields and from DOY 167, 169, 174, 182, 184, and 189. A detailed description of the micro-meteorological data, net radiation, crop biophysical characteristics, and instrumentation setup can be found in [30].

Table 1 below, and Table A1 in Appendix A summarize the available data used in this study. Nine (9) independent variables were used to predict one (1) dependent variable. The independent variables were: net radiation $\left(R_{n}\right)$, horizontal wind speed $(U)$, air temperature $\left(T_{\text {air }}\right)$, relative humidity $(R H)$, aerodynamic resistance $\left(r_{a h}\right)$, surface temperature from airborne remote sensing (Ts RS), leaf area index (LAI), crop height $\left(\mathrm{h}_{\mathrm{c}}\right)$, and the height of wind speed measurement $\left(\mathrm{Z}_{\mathrm{m}}\right)$. The dependent variable was the soil heat flux $(\mathrm{G})$. There were 50 records for each variable.

Table 1. Summary of available data.

\begin{tabular}{|c|c|c|c|c|c|c|c|c|c|c|}
\hline & $\begin{array}{c}\mathbf{R}_{\mathbf{n}} \\
\mathbf{W} \mathbf{~ m}^{-2} \\
\end{array}$ & $\begin{array}{c}\mathbf{G} \\
\mathbf{W} \mathbf{m}^{-2} \\
\end{array}$ & $\begin{array}{c}\mathbf{U} \\
\mathrm{m} \mathrm{s}^{-1} \\
\end{array}$ & $\begin{array}{l}\mathbf{T}_{\text {air }} \\
{ }^{\circ} \mathbf{C} \\
\end{array}$ & $\begin{array}{c}\text { RH } \\
\% \\
\end{array}$ & $\begin{array}{c}\mathbf{r}_{\mathrm{ah}} \\
\mathrm{s} \mathrm{m}^{-1} \\
\end{array}$ & $\begin{array}{c}\text { Ts_RS } \\
{ }^{\circ} \mathbf{C} \\
\end{array}$ & $\begin{array}{c}\text { LAI } \\
\mathbf{m}^{2} \mathbf{m}^{-2}\end{array}$ & $\begin{array}{l}\mathbf{h}_{\mathbf{c}} \\
\mathbf{m} \\
\end{array}$ & $\begin{array}{c}\mathbf{Z}_{\mathbf{m}} \\
\mathbf{m} \\
\end{array}$ \\
\hline Mean & 592.0 & 115.8 & 4.3 & 28.2 & 49.3 & 31.9 & 36.6 & 2.1 & 0.8 & 2.9 \\
\hline StDev & 67.1 & 65.3 & 1.9 & 3.0 & 13.8 & 14.1 & 4.1 & 1.4 & 0.6 & 0.8 \\
\hline $\operatorname{Max}$ & 684.0 & 292.0 & 7.6 & 33.0 & 75.8 & 65.5 & 44.4 & 5.0 & 2.0 & 5.0 \\
\hline Min & 357.0 & 15.0 & 1.5 & 23.0 & 27.6 & 14.9 & 30.4 & 0.2 & 0.1 & 1.8 \\
\hline
\end{tabular}

As shown in [7] and [10], $G$ has been related to $R_{n}$ and VI with good success. In this study, $G$ was also thought to be related to $U$ because of the ability of wind to remove heat from the surface [5,30]. In this regard, also the height of the wind speed readings was included because this height along with the 
roughness of the surface will dictate the magnitude of wind recorded. Similarly, $\mathrm{r}_{\text {ah }}$ was used in this study because it encapsulates surface conditions as vegetation roughness, $U, Z_{m}$, and $h_{c}$. In the case of $\mathrm{T}_{\text {air }}$ and $\mathrm{RH}$, they were included in the analysis considering that they could be an indication of the capacity of the atmosphere to retain and/or transmit heat to the surface. Ts RS was also included since surface temperature, along with VI, captured using remote sensing techniques can be instrumental in distinguishing vegetated/bare and dry/wet surfaces [30]. Finally, LAI was included because it is known [5] that the larger the value of LAI the smaller the fraction $G / R_{n}$.

\subsection{ANN Models}

The development of a model for a particular type of artificial neural network includes the selection of the number of layers, activation functions, and training algorithms for the network. Figure 1 shows a schematic of the initial neural network model used in this study, consisting of the input layer with nine (9) nodes or units (independent variables), one hidden layer with four (4) nodes, and the output layer with one (1) node ( $G$, the dependent variable). The nodes of one layer are connected to the nodes of the other layers by synapses (weights), and combined using specific transfer functions. Predicted values at the output layer are compared with observed values and, if necessary, weights are adjusted and the process is repeated. The models referred to in this study correspond to regression models.

Figure 1. Schematic of the initial artificial neural network model.

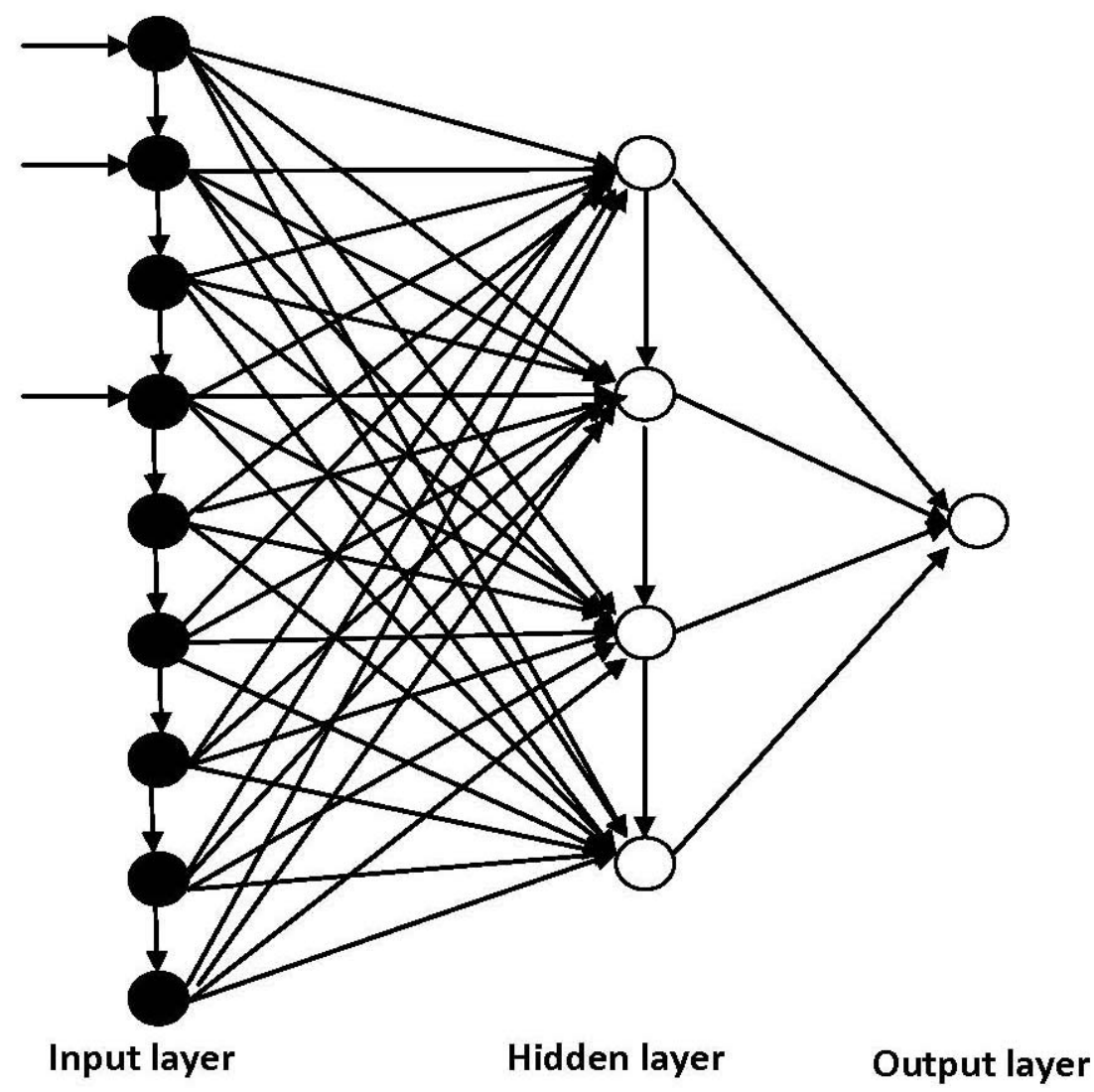

Once the initial model, using all 9 independent variables, was analyzed, additional models were constructed using $8,7,6,5,4,3$ and 2 independent variables. The goal was to find a high performance model developed with the fewest possible independent variables. The independent variables were 
combined using the Multinomial Coefficient $\left(\mathrm{C}_{\mathrm{n}, \mathrm{k}}\right)$, which is a generalization of the Binomial Coefficient [31,32], and which allows to select subsets of $k$ elements from a set of $n$ elements without repetitions:

$$
C_{n, k}=\frac{n !}{k !(n-k) !}
$$

where

$\mathrm{C}_{\mathrm{n}, \mathrm{k}} \quad$ Number of possible subsets of $\mathrm{k}$ from the set of $\mathrm{n}$;

$\mathrm{n} \quad$ Total number of independent variables (size of the set);

$\mathrm{k} \quad$ Number of independent variables to be grouped from the set $\mathrm{n}>\mathrm{k}$.

\subsubsection{ANN Software}

Once all models were constructed, an artificial neural network software was used to train and test them. The ANN software used in this project was the NeuroIntelligence V.2.2 from Alyuda Research, Inc. [33], which includes a friendly user interface and a number of options for the different stages of the analysis.

\subsubsection{Data Preprocessing}

The available data were randomly divided into three sets: $70 \%$ for training the algorithms, $15 \%$ for validation, and $15 \%$ for testing the results obtained from the adopted ANN. This division can also be performed following a specific pattern, and the percentages used for training, validation, and testing can also be different than the ones used in this study. Due to the small size of the data set available, the existing anomalies in the data, such as missing values and outliers, were replaced by the average value rather than discarding them. This approach, however, could introduce distortions in the model. Additionally, all variables involved were treated as numerical values, and were scaled into an appropriate range $[-1,1]$ before their entry in the network.

\subsubsection{Type of Network}

There are many types of ANN, which can be classified according to several criteria: need of supervision, architecture, training algorithm, task performed, etc. Neuro-intelligence utilizes a supervised type of network called Multiple Layer Perceptron (MLP), very suited for prediction tasks [33]. This latter ANN type was the one selected for our study.

\subsubsection{Network Architecture}

To design a network, it is necessary to specify the network architecture (number of hidden layers and nodes, or neurons, in each layer) and network properties (error and activation functions). For our case, an architecture consisting one (1) hidden layer was selected, with the number of neurons for this layer equal to half neurons of the input layer. The number of neurons in the input layer was in itself a variable which changed as the number of independent variables was changing (from 9 to 2). The output layer consisted of only one neuron for all cases, G (the dependent variable). The activation functions used for both the hidden and the output layers were logistic and hyperbolic tangent [34,35]. 


\subsubsection{Training Algorithms}

All training algorithms supported by NeuroIntelligence were applied to the analysis of the data. Those training algorithms were: Quick Propagation (QP), Conjugate Gradient Descent (CGD), Quasi-Newton (Q-N), Limited Memory Quasi-Newton (LMQ-N), Levenberg-Marquardt (L-M), Online Back Propagation (OBP), and Batch Back Propagation (BBP).

\subsubsection{Termination Criterion}

The termination criterion (when to stop training) used was the number of iterations. A number of 1,000 iterations were used each time a new configuration was trained.

\subsubsection{Testing}

The performance of each network model was assessed numerically using both the Correlation Coefficient, $r[-1,1]$ and the Coefficient of Determination, $\mathrm{R}^{2}[-1,1]$. It is convenient to note that $\mathrm{R}^{2}$ is equal to $\mathrm{r}^{2}$ in linear regression analyses, but that is not necessarily the case in ANN. The testing was conducted for all data sets: training, validation, and testing. If the coefficients did not reach the minimum values accepted ( $r$ and $R^{2} \geq 0.90$ ) then the network was re-trained by adjusting the weights (jogging), choosing a different training algorithm or changing the activation functions. When the models included only 2-3 independent variables in the input layer, the performance requirements were lowered ( $\mathrm{r}$ and $\mathrm{R}^{2} \geq 0.80$ ) due to the increasing difficulty of correctly predicting the dependent variable, $\mathrm{G}$.

\section{Results and Discussion}

Table 2 shows the performance of one (1) ANN model created using all nine independent variables. All training algorithms were used to estimate $\mathrm{G}$, the dependent variable. Results showed that, for most cases, values of both the Correlation Coefficient ( $\mathrm{r}$ ) and the Coefficient of Determination $\left(\mathrm{R}^{2}\right)$ were very high ( $r$ and $R^{2} \geq 0.90$ ), particularly for the Training step which uses $70 \%$ of the available data. The Testing component is the only one that uses unseen data and, for most cases, the performance of the model was not very good ( $\mathrm{r}$ and $\mathrm{R}^{2}<<0.90$ ) probably due to the small size of the data set available compared to the number of independent variables used initially. It was not necessary to switch from Logistic to Hyperbolic Tangent activation function to obtain those values. Overall, the performance of the model was very good for the training and validation phases, reaching values of both $\mathrm{r}$ and $\mathrm{R}^{2} \geq 0.90$. However, the analysis included all independent variables and therefore we cannot determine with precision at this point the variables that affect the dependent variable $(G)$ the most. In view of this, additional models with fewer independent variables were needed. The process of reducing the number of independent variables, in this study, was based on the performance of the models. Additional techniques that can be applied include the Proper Orthogonal Decomposition (POD), the Principal Component Analysis (PCA), and others. 
Table 2. Performance of the ANN model created using all independent variables and training algorithms.

\begin{tabular}{ccccccccccc}
\hline $\begin{array}{c}\text { Independent } \\
\text { Variables }\end{array}$ & $\begin{array}{c}\text { Transfer } \\
\text { Function }\end{array}$ & $\begin{array}{c}\text { Train. } \\
\text { Algor. }\end{array}$ & \multicolumn{3}{c}{$\begin{array}{c}\text { Correlation Coefficient } \\
(\mathbf{r})\end{array}$} & \multicolumn{3}{c}{ Coefficient of Determination } \\
& & Train. & Valid. & Test. & All & Train. & Valid. & Test. & All \\
\hline \multirow{2}{*}{$\mathrm{Z}_{\mathrm{m}}, \mathrm{h}_{\mathrm{c}}}$, & Logistic & QP & 0.98 & 0.96 & 0.96 & 0.96 & 0.95 & 0.92 & 0.91 & 0.94 \\
LAI, & Logistic & CGD & 1.00 & 0.99 & 0.88 & 0.97 & 0.99 & 0.96 & 0.71 & 0.93 \\
Ts RS, & Logistic & Q-N & 0.98 & 1.00 & 0.94 & 0.97 & 0.95 & 0.98 & 0.83 & 0.93 \\
$\mathrm{r}_{\text {ah }}, \mathrm{RH}$, & Logistic & LMQ-N & 0.98 & 0.99 & 0.84 & 0.96 & 0.95 & 0.96 & 0.62 & 0.90 \\
$\mathrm{~T}_{\text {air }}, \mathrm{U}$, & Logistic & L-M & 0.97 & 0.99 & 0.92 & 0.95 & 0.92 & 0.95 & 0.64 & 0.89 \\
$\mathrm{R}_{\mathrm{n}}$ & Logistic & OBP & 0.95 & 0.92 & 0.91 & 0.93 & 0.87 & 0.84 & 0.76 & 0.85 \\
& Logistic & BBP & 0.96 & 0.97 & 0.83 & 0.93 & 0.93 & 0.81 & 0.16 & 0.89 \\
\hline
\end{tabular}

Table 3 presents the performance of nine (9) ANN models created with combinations of eight (8) independent variables $\left(9=9 ! /\left(\left(8 !^{*}(9-8) !\right)\right)\right.$. Once more, high values of $r$ and $\mathrm{R}^{2}(\geq 90)$ were obtained for all Training cases. For most cases, the Quick Propagation training algorithm (the first one tried) was enough to reach those values. However, in two cases it was necessary to switch from Logistic to Hyperbolic Tangent activation functions. At this stage, low values for $\mathrm{R}^{2}(<<0.90)$ started to show during the Validation and Testing steps. It seems that the large number of independent variables included in each model resulted in high values of $\mathrm{r}$ and $\mathrm{R}^{2}$, and that the removal of one variable did not affect significantly the model performance (values of $\mathrm{r}$ and $\mathrm{R}^{2}$ still above 0.90 for all models during the Training step). However, additional models with fewer independent variables still seem to be needed to narrow down the true or appropriate variables that properly model G.

Table 3. Performance of ANN using combinations of eight independent variables.

\begin{tabular}{|c|c|c|c|c|c|c|c|c|c|c|}
\hline \multirow{2}{*}{$\begin{array}{l}\text { Independent Variables } \\
\text { (using 8, removing } 1 \text { ) }\end{array}$} & \multirow{2}{*}{$\begin{array}{l}\text { Transfer } \\
\text { Function }\end{array}$} & \multirow{2}{*}{$\begin{array}{l}\text { Train. } \\
\text { Algor. }\end{array}$} & \multicolumn{4}{|c|}{$\begin{array}{c}\text { Correlation Coefficient } \\
\text { (r) }\end{array}$} & \multicolumn{4}{|c|}{$\begin{array}{l}\text { Coefficient of Determination } \\
\qquad\left(\mathbf{R}^{2}\right)\end{array}$} \\
\hline & & & Train. & Valid. & Test. & All & Train. & Valid. & Test. & All \\
\hline $\begin{array}{l}\mathrm{h}_{\mathrm{c}}, \mathrm{LAI}, \mathrm{Ts} \mathrm{RS}, \mathrm{r}_{\mathrm{ah}} \\
\quad \mathrm{RH}, \mathrm{T}_{\mathrm{air}}, \mathrm{U}, \mathrm{R}_{\mathrm{n}}\end{array}$ & Logistic & QP & 0.99 & 0.98 & 0.92 & 0.95 & 0.98 & 0.91 & 0.58 & 0.90 \\
\hline $\begin{array}{l}\mathrm{Z}_{\mathrm{m}}, \mathrm{LAI}, \mathrm{Ts} \mathrm{RS}, \mathrm{r}_{\mathrm{ah}} \\
\mathrm{RH}, \mathrm{T}_{\mathrm{air}}, \mathrm{U}, \mathrm{R}_{\mathrm{n}}\end{array}$ & Logistic & QP & 1.00 & 0.91 & 0.90 & 0.96 & 0.99 & 0.80 & 0.58 & 0.92 \\
\hline $\begin{array}{l}\mathrm{Z}_{\mathrm{m}}, \mathrm{h}_{\mathrm{c}}, \mathrm{Ts} \mathrm{RS}, \mathrm{r}_{\mathrm{ah}} \\
\mathrm{RH}, \mathrm{T}_{\mathrm{air}}, \mathrm{U}, \mathrm{R}_{\mathrm{n}}\end{array}$ & Logistic & QP & 0.97 & 0.95 & 0.73 & 0.96 & 0.92 & 0.88 & 0.60 & 0.90 \\
\hline $\begin{array}{l}\mathrm{Z}_{\mathrm{m}}, \mathrm{h}_{\mathrm{c}}, \mathrm{LAI}, \mathrm{r}_{\mathrm{ah}} \\
\mathrm{RH}, \mathrm{T}_{\mathrm{air}}, \mathrm{U}, \mathrm{R}_{\mathrm{n}}\end{array}$ & Logistic & LMQ-N & 0.96 & 0.95 & 0.93 & 0.95 & 0.93 & 0.83 & 0.54 & 0.87 \\
\hline $\begin{array}{c}\mathrm{Z}_{\mathrm{m}}, \mathrm{h}_{\mathrm{c}}, \mathrm{LAI}, \mathrm{Ts} \mathrm{RS} \\
\mathrm{RH}, \mathrm{T}_{\text {air }}, \mathrm{U}, \mathrm{R}_{\mathrm{n}}\end{array}$ & Logistic & OBP & 0.95 & 0.83 & 0.97 & 0.95 & 0.91 & 0.60 & 0.93 & 0.89 \\
\hline $\begin{array}{c}\mathrm{Z}_{\mathrm{m}}, \mathrm{h}_{\mathrm{c}}, \mathrm{LAI}, \mathrm{Ts} \mathrm{RS} \\
\mathrm{r}_{\mathrm{ah}}, \mathrm{T}_{\mathrm{air}}, \mathrm{U}, \mathrm{R}_{\mathrm{n}}\end{array}$ & Logistic & QP & 0.97 & 0.93 & 0.92 & 0.95 & 0.94 & 0.86 & 0.64 & 0.90 \\
\hline $\begin{array}{c}\mathrm{Z}_{\mathrm{m}}, \mathrm{h}_{\mathrm{c}}, \mathrm{LAI}, \mathrm{Ts} \mathrm{RS} \\
\mathrm{RS}, \mathrm{r}_{\mathrm{ah}}, \mathrm{U}, \mathrm{R}_{\mathrm{n}}\end{array}$ & Hyp. Tan. & QP & 0.95 & 0.90 & 0.96 & 0.93 & 0.90 & 0.80 & 0.69 & 0.85 \\
\hline $\begin{array}{c}\mathrm{Z}_{\mathrm{m}}, \mathrm{h}_{\mathrm{c}}, \mathrm{LAI}, \mathrm{Ts} \mathrm{RS} \\
\mathrm{r}_{\mathrm{ah}}, \mathrm{RH}, \mathrm{T}_{\mathrm{air}}, \mathrm{R}_{\mathrm{n}}\end{array}$ & Hyp. Tan. & QP & 0.97 & 0.93 & 0.83 & 0.94 & 0.94 & 0.76 & 0.67 & 0.88 \\
\hline $\begin{array}{c}\mathrm{Z}_{\mathrm{m}}, \mathrm{h}_{\mathrm{c}}, \mathrm{LAI}, \mathrm{Ts} \mathrm{RS} \\
\mathrm{r}_{\mathrm{ah}}, \mathrm{RH}, \mathrm{T}_{\mathrm{air}}, \mathrm{U}\end{array}$ & Logistic & QP & 0.95 & 0.99 & 0.96 & 0.95 & 0.91 & 0.85 & 0.90 & 0.90 \\
\hline
\end{tabular}


Table A2 in Appendix A presents the performance of thirty six (36) ANN models created with combinations of seven (7) independent variables $\left(36=9 ! /((7 ! *(9-7) !))\right.$. Again, high values of $r$ and $\mathrm{R}^{2}$ ( $\geq 90)$ were obtained for all Training cases, and the Logistic activation function was used for most cases; however, it was necessary to try more training algorithms, mainly the Conjugate Gradient Descent and the Quasi-Newton to obtain high performance values. As seen in the models of eight independent variables, relatively low values of $\mathrm{R}^{2}$ occur in some cases during the Validation and Testing steps. Due to the fact that, at this point, all models meet the performance criteria, additional independent variables need to be removed from subsequent models in order to determine driving forces in the estimation of the dependent variable $(G)$.

When the number of independent variables was reduced to six (6), five (5), and four (4), respectively, the resulting ANN models started to fail to reach the minimum threshold values set as acceptable ( $r$ and $R^{2} \geq 0.90$ for Training). This failure indicated that some independent variables, which were dropped from the analysis, were driving forces in the estimation of $\mathrm{G}$ and, therefore, their inclusion in the process was necessary in models with fewer independent variables to produce a successful ANN model for soil heat flux. Examples of those variables were $R_{n}$ (mainly), LAI, $T_{\text {air }}, U$, and/or RH.

Table 4 presents the performance of ANN models constructed with combinations of three independent variables only. As it is shown, in some cases the minimum values of $\mathrm{r}$ and $\mathrm{R}^{2}$ (initially set as $\geq 0.90$ ) were not totally reached, even when using the two activation functions and the seven training algorithms.

Table 4. Performance of ANN using combinations of three independent variables.

\begin{tabular}{|c|c|c|c|c|c|c|c|c|c|c|}
\hline \multirow{2}{*}{$\begin{array}{c}\text { Independent } \\
\text { Variables } \\
\left(\text { keeping } \mathbf{T}_{\text {air }} \text { and } R_{n}\right)\end{array}$} & \multirow{2}{*}{$\begin{array}{l}\text { Transfer } \\
\text { Function }\end{array}$} & \multirow{2}{*}{$\begin{array}{l}\text { Train. } \\
\text { Algor. }\end{array}$} & \multicolumn{4}{|c|}{$\begin{array}{c}\text { Correlation Coefficient } \\
\text { (r) }\end{array}$} & \multicolumn{4}{|c|}{$\begin{array}{c}\text { Coefficient of Determination } \\
\qquad\left(\mathbf{R}^{2}\right)\end{array}$} \\
\hline & & & Train. & Valid. & Test. & All & Train. & Valid. & Test. & All \\
\hline $\mathrm{R}_{\mathrm{n}}, \mathrm{T}_{\text {air }}, \mathrm{Z}_{\mathrm{m}}$ & Logistic & Q-N & 0.95 & 0.82 & 0.88 & 0.92 & 0.92 & 0.59 & 0.62 & 0.85 \\
\hline $\mathrm{R}_{\mathrm{n}}, \mathrm{T}_{\mathrm{air}}, \mathrm{h}_{\mathrm{c}}$ & Hyp. Tan. & LMQ-N & 0.95 & 0.92 & 0.95 & 0.94 & 0.90 & 0.75 & 0.90 & 0.89 \\
\hline $\mathrm{R}_{\mathrm{n}}, \mathrm{T}_{\mathrm{air}}, \mathrm{r}_{\mathrm{ah}}$ & Hyp. Tang. & CGD & 0.87 & 0.89 & 0.85 & 0.86 & 0.75 & 0.61 & 0.69 & 0.72 \\
\hline $\mathrm{R}_{\mathrm{n}}, \mathrm{T}_{\mathrm{air}}, \mathrm{LAI}$ & Logistic & L-M & 0.92 & 0.96 & 0.65 & 0.88 & 0.85 & 0.90 & 0.27 & 0.78 \\
\hline $\mathrm{R}_{\mathrm{n}}, \mathrm{T}_{\text {air }}, \mathrm{RH}$ & Hyp. Tan. & LMQ-N & 0.95 & 0.84 & 0.96 & 0.94 & 0.88 & 0.34 & 0.89 & 0.86 \\
\hline $\mathrm{R}_{\mathrm{n}}, \mathrm{T}_{\text {air }}, \mathrm{Ts} \mathrm{RS}$ & Logistic & CGD & 0.90 & 0.90 & 0.89 & 0.88 & 0.80 & 0.79 & 0.36 & 0.74 \\
\hline $\mathrm{R}_{\mathrm{n}}, \mathrm{T}_{\mathrm{air}}, \mathrm{U}$ & Logistic & CGD & 0.88 & 0.94 & 0.78 & 0.88 & 0.76 & 0.80 & 0.61 & 0.75 \\
\hline
\end{tabular}

Good independent variables in the modeling of $\mathrm{G}$, with $\mathrm{r}$ and $\mathrm{R}^{2}$ values very close to target values, appear to be the combination of $R_{n}$ with $T_{\text {air }}$ and $h_{c}$, and $R_{n}$ with $T_{\text {air }}$ and $R H$. The combination of $R_{n}$ with $T_{\text {air }}$ and $h_{c}$ is preferred over $R_{n}$ with $T_{\text {air }}$ and $R H$ because the former combination includes the variable "crop/vegetation height" which is a measure of the amount of biomass (that can be modeled with remote sensing algorithms) that plays a role in the regulation of the energy transferred to the ground. In contrast, the combination $\mathrm{R}_{\mathrm{n}}$ with $\mathrm{T}_{\text {air }}$ and $\mathrm{RH}$ does not include the vegetation on the surface in any direct way. In addition, $\mathrm{RH}$ already includes $\mathrm{T}_{\text {air }}$ in the form of saturation vapor pressure.

Values of $r$ and $R^{2} \geq 0.80$ are still indicators of good performance for the models. Therefore, it was decided to lower the set threshold of $r$ and $R^{2}$ to $\geq 0.80$ and further try combinations of only two independent variables. 
Finally, Table 5 shows the performance of ANN models constructed with combinations of only two independent variables. In those cases, it was even more difficult to obtain high values of $r$ and $\mathrm{R}^{2}$. However, the combinations $\mathrm{R}_{n}$ with LAI, and $\mathrm{R}_{n}$ with $\mathrm{RH}$ seem to consistently perform better, particularly for Training, showing the largest values of $r$. Other combinations failed, even using the two (2) transfer functions and the seven (7) training algorithms available in Neurointelligence.

Table 5. Performance of ANN using combinations of two independent variables.

\begin{tabular}{|c|c|c|c|c|c|c|c|c|c|c|}
\hline \multirow{2}{*}{$\begin{array}{c}\text { Independent } \\
\text { Variables } \\
\text { (keeping Rn) }\end{array}$} & \multirow{2}{*}{$\begin{array}{l}\text { Transfer } \\
\text { Function }\end{array}$} & \multirow{2}{*}{$\begin{array}{l}\text { Train. } \\
\text { Algor. }\end{array}$} & \multicolumn{4}{|c|}{$\begin{array}{c}\text { Correlation Coefficient } \\
\text { (r) }\end{array}$} & \multicolumn{4}{|c|}{$\begin{array}{c}\text { Coefficient of Determination } \\
\left(\mathbf{R}^{2}\right)\end{array}$} \\
\hline & & & Train. & Valid. & Test. & All & Train. & Valid. & Test. & All \\
\hline $\mathrm{R}_{\mathrm{n}}, \mathrm{h}_{\mathrm{c}}$ & Hyp. Tan. & CGD & 0.86 & 0.75 & 0.98 & 0.82 & 0.72 & 0.22 & 0.70 & 0.65 \\
\hline $\mathrm{R}_{\mathrm{n}}, \mathrm{r}_{\mathrm{ah}}$ & Logistic & $\mathrm{QP}$ & 0.88 & 0.83 & 0.86 & 0.86 & 0.73 & 0.51 & 0.68 & 0.70 \\
\hline $\mathrm{R}_{\mathrm{n}}, \mathrm{RH}$ & Logistic & CGD & 0.90 & 0.83 & 0.91 & 0.84 & 0.76 & 0.21 & 0.33 & 0.61 \\
\hline $\mathrm{R}_{\mathrm{n}}$, LAI & Logistic & CGD & 0.91 & 0.79 & 0.87 & 0.90 & 0.80 & 0.30 & 0.37 & 0.76 \\
\hline $\mathrm{R}_{\mathrm{n}}, \mathrm{U}$ & Hyp. Tan. & OBP & 0.78 & 0.53 & 0.99 & 0.78 & 0.52 & 0.26 & 0.91 & 0.55 \\
\hline $\mathrm{R}_{\mathrm{n}}, \mathrm{T}_{\mathrm{air}}$ & Logistic & CGD & 0.80 & 0.98 & 0.90 & 0.83 & 0.60 & 0.95 & 0.63 & 0.66 \\
\hline
\end{tabular}

However, the combination $\mathrm{R}_{\mathrm{n}}$ with $\mathrm{RH}$ did not yield a high overall coefficient of determination $\left(\mathrm{R}^{2}\right)$ and, physically, relative humidity cannot explain the transfer of energy from the surface to the ground only by itself as discussed above when considering the combination of three independent variables. For this reason, this combination was discarded and was not considered representative for modeling soil heat flux with only two independent variables. In contrast, the combination $R_{n}$ with $r_{\text {ah }}$ resulted overall in a relatively lower $r$ of 0.86 (if compared with $r=0.90$, the threshold value) but with a larger $R^{2}$ of 0.70 when compared to the combination $R_{n}$ with $R H$. This result (combination of $R_{n}$ with $r_{a h}$ ) seems to be a better option because the surface aerodynamic resistance $\left(\mathrm{r}_{\mathrm{ah}}\right)$ considers biomass (in the form of surface roughness length and crop/vegetation height) and wind speed (U). Both biomass amount and wind speed affect the way in which the net radiation energy at the surface is transferred to the underlying soil strata and thus $r_{a h}$ appears to be a good explanatory variable in the modeling of $G$. Therefore, the combination $\mathrm{R}_{\mathrm{n}}$ with $\mathrm{r}_{\mathrm{ah}}$ has been selected as the second combination that successfully modeled soil heat flux $(\mathrm{G})$ using ANN along with the combination $\mathrm{R}_{\mathrm{n}}$ with LAI.

\section{Conclusions}

Artificial Neural Networks (ANNs) represent a novel technique that can be successfully implemented to estimate Soil Heat Flux $(\mathrm{G})$ as preliminary demonstrated in this study and evidenced by the performance of the constructed models. In this study, it was possible to obtain relatively good performance values in the form of large correlation coefficients $r$ and coefficients of determination $\mathrm{R}^{2}$ for the estimation of G using only three and two independent variables in the construction of the ANN models; even though the size of the data was relatively small. Data sets consisting of 100 or more observed values are more desirable.

The performance of the ANN model for the Testing and Validation steps were, in some cases, low if compared to the Training step. This was probably due to the small number of observations used (7-8 for Validation, 7-8 for Testing, and 35 for Training) in relation to the number of independent variables 
considered. Nevertheless, net radiation $\left(R_{n}\right)$ resulted being the main driving force behind $G$, as it was present in all successful combination models including combination of three and two independent variables. Furthermore, the combination of $R_{n}$ with $T_{\text {air }}$ and $h_{c}$ seems to better reproduce measured values of $G$, when three independent variables were considered; while the combination of $R_{n}$ with $r_{a h}$ and $R_{n}$ with LAI followed as second and third choices, respectively, when two independent variables were considered. In addition, it is suggested that $\mathrm{T}_{\text {air }}$ be included as an important variable in future estimations using larger datasets because it was present in all successful models with three variables.

Therefore, this study showed that it was possible to model soil heat flux using ANN and remote sensing derived independent variables.

The software used in this study, Neurointelligence, proved to be powerful yet easy to use; however, it included only one type on neural networks (multiple layer perceptron). It is recommended to try different types of neural networks in future studies, as well as other approaches for data division and independent variables reduction.

\section{Acknowledgements}

We are thankful to NASA and to the following individuals who were involved in the data collection and processing: Bill Kustas (USDA-ARS), John Prueger (USDA-ARS), Christopher Neale (Utah State University), Larry Hipps (Utah State University), and Martha Anderson (USDA-ARS). Also, we express our sincere appreciation to anonymous reviewers who helped improve the quality of the article.

\section{References}

1. Gowda, P.H.; Chavez, J.L.; Colaizzi, P.D.; Evett, S.R.; Howell, T.A.; Tolk, J.A. ET mapping for agricultural water management: Present status and Challenges. Irrig. Sci. 2008, 26, 223-237.

2. Ahmed, R.H. Estimating Crop Water Requirements of a Command Area Using Multispectral Video Imagery and Geographic Information Systems. Ph.D. Thesis, Biological and Irrigation Engineering Department, Utah State University, Logan, UT, USA, 1997.

3. Payero, J.O. Estimating Evapotranspiration of Reference Crops Using the Remote Sensing Approach. Ph.D. Thesis, Biological and Irrigation Engineering Department, Utah State University, Logan, UT, USA, 1997.

4. Neale, C.M.U.; Hipps, L.E.; Prueger, J.H.; Kustas, W.P.; Cooper, D.I.; Eichinger, W.E. Spatial Mapping of Evapotranspiration and Energy Balance Components Over Riparian Vegetation Using Airborne Remote Sensing. In Proceedings of Remote Sensing and Hydrology 2000, Santa Fe, NM, USA, 2-7 April 2000; pp. 311-315.

5. Chávez, J.L. Validating Surface Energy Balance Fluxes Derived from Airborne Remote Sensing. Ph.D. Thesis, Biological and Irrigation Engineering Department, Utah State University, Logan, UT, USA, 2005.

6. Chavez, J.L.; Howell, T.A.; Gowda, P.; Neale, C.M.; Colaizzi, P.D. Evaluating Airborne Remote Sensing ET Estimates Using Eddy Covariance Systems and a Heat Flux Source Area Function. In Proceedings of Irrigation Association Conference, Anaheim, CA, USA, 2-4 November 2008; Paper No IA09-1013, pp. 1-29, [CDROM]. 
7. Clothier, B.E.; Clawson, K.L.; Pinter, P.J.; Moran, M.S.; Reginato, R.G.; Jackson, R.D. Estimation of soil heat flux from net radiation during the growth of alfalfa. Agr. Forest Meteorol. 1986, 37, 319-329.

8. Sene, K.J. Parameterisations for energy transfers from a sparse vine crop. Agr. Forest Meteorol. 1994, 71, 1-18.

9. Choudhury, B.J.; Reginato, R.J.; Idso, S.B. An analysis of infrared temperature observations over wheat and calculation of latent heat flux. Agr. Forest Meteorol. 1986, 37, 75-88.

10. Kustas, W.P.; Daughtry, C.S.T. Estimation of soil heat flux/net radiation ration from spectral data. Agr. Forest Meteorol. 1990, 49, 205-223.

11. Abdalla, S.H.; Neale, C.M.U.; Malek, E.; Hipps, L. Estimation of Net Radiation of Sparse Vegetation Using Multispectral Video Imagery. In Proceedings of 16th Annual American Geophysical Union Hydrology Days, Fort Collins, CO, USA, 15-18 April 1996.

12. Choudhury, B.J.; Idso, S.B.; Reginato, R.J. Analysis of an empirical model for soil heat flux under a growing wheat crop for estimating evaporation by an infrared based energy balance equation. Agr. Forest Meteorol. 1987, 39, 283-297.

13. Therdthai, N.; Zhou, W. Artificial neural network modelling of the electrical conductivity property of recombined milk. J. Food Eng. 2004, 50, 107-111.

14. Silverman, D.; Dracup, J.A. Artificial neural networks and long-range precipitation prediction in California. Am. Meteorol. Soc. 2000, 39, 57-66.

15. Daliakopoulos, I.N.; Coulibaliy, P.; Tsanis, I.K. Groundwater level forecasting using artificial neural networks. J. Hydrol. 2005, 309, 229-240.

16. Melesse, A.M.; Hanley, R.S. Artificial neural network application for multi-ecosystem carbon flux simulation. Ecol. Model. 2005, 189, 305-314.

17. Akratos, C.S.; Papaspyros, J.N.E.; Tsihrintzis, V.A. Total nitrogen and ammonia removal prediction in horizontal subsurface flow constructed wetlands: Use of artificial neural networks and development of a design equation. Biores. Technol. 2009, 100, 586-596.

18. Zanetti, S.S.; Sousa, E.F.; Oliveira, V.P.S.; Almeida, F.T.; Bernardo, F. Estimating evapotranspiration using artificial neural network and minimum climatological data. J. Irrig. Drain. Eng. 2007, 133, 83-89.

19. Kain, S.K.; Nayak, P.C.; Sudheer, K.P. Models for estimating evapotranspiration using artificial neural networks, and their physical interpretation. Hydrol. Process. 2008, 22, 2225-2234.

20. Kumar, M.; Raghuwanshi, N.S.; Sigh, R. Artificial neural networks approach in evapotranspiration modeling: A review. Irrig. Sci. 2011, 29, 11-25.

21. Khoob, A.R. Comparative study of Hargreaves's and artificial neural network's methodologies in estimating reference evapotranspiration in a semiarid environment. Irrig. Sci. 2008, 26, 253-259.

22. Kustas, W.P.; Hatfield, J.L.; Prueger, J.H. The soil moisture atmosphere coupling experiment (SMACEX) background, hydro-meteorological conditions and preliminary findings. $J$. Hydrometeor. 2005, 6, 791-804.

23. Neale, C.M.U.; Crowther, B. An airborne multispectral video/radiometer remote sensing system:development and calibration. Remote Sens. Environ. 1994, 49, 187-194. 
24. Cai, B.; Neale, C.M.U. A Method for Constructing Three Dimensional Models from Airborne Imagery. In Proceedings of the 17th Biennial Workshop on Color Photography and Videography in Resource Assessment, Reno, NV, USA, 5-7 May 1999.

25. Sundararaman, S.; Neale, C.M.U. Geometric Calibration of the USU Videography System. In Proceedings of 16th Biennial Workshop on Videography and Color Photography for Resource Assessment, Weslaco, TX, USA, 29 April-1 May 1997.

26. Jackson, R.D.; Clarke, T.R.; Moran, M.S. Bidirectional calibration results of 11 Spectralon and 16 $\mathrm{BaSO}_{4}$ reference reflectance panels. Remote Sens. Environ. 1992, 40, 231-239.

27. Berk, A.; Bernstein, L.S.; Robertson, D.C. MODTRAN: A Moderate Resolution Model for LOWTRAN 7; Report GL-TR-89-0122; US Aire Force Geophysics Laboratory: Bedford, MD, USA, 1989.

28. Hipps, L. The infrared emissivity of soil and artemisia tridendata and subsequent temperature corrections in a shrub-steppe ecosystem. Remote Sens. Environ. 1989, 27, 337-342.

29. Brunsell, N.A.; Gillies, R. Incorporating surface emissivity into a thermal atmospheric correction. Photogramme. Eng. Remote Sensing 2002, 68, 1263-1269.

30. Chávez, J.L.; Neale, C.M.U.; Hipps, L.E.; Prueger, J.H.; Kustas, W.P. Comparing aircraft-based remotely sensed energy balance fluxes with eddy covariance tower data using heat flux source area functions. J. Hydrometeor. 2005, 6, 923-940.

31. Kinvalina, J. A unified interpretation of the binomial coefficients, the stirling numbers, and the gaussian coefficients. Am. Math. Mon. 2000. 107, 901-910.

32. Sofo, A. General properties involving reciprocals of binomial coefficients. J. Integer Seq. 2006, 9 , article 06.4.5.

33. Neurointelligence; Alyuda Research, Inc.: Cupertino, CA, USA, 2010. Available online: $\mathrm{http}: / /$ www.alyuda.com/ (accessed on 10 September 2010).

34. Jain, A.K.; Mao, J. Artificial networks: A tutorial. Computer 1996, 9, 31-44.

35. Hagan, M.; Demuth, H.; Beale, M. Neural Network Design, 1st ed.; Brooks/Cole Publishing Company: Pacific Grove, CA, USA, 1996.

\section{Appendix}

Table A1. Available Data used to perform the ANN application to model soil heat flux.

\begin{tabular}{|c|c|c|c|c|c|c|c|c|c|}
\hline $\begin{array}{c}\mathbf{R}_{\mathbf{n}} \\
\mathbf{W ~ m ~}^{-\mathbf{2}}\end{array}$ & $\begin{array}{c}\mathbf{G} \\
\mathbf{W ~ m}^{-\mathbf{2}}\end{array}$ & $\begin{array}{c}\mathbf{U} \\
\mathbf{m ~ s}^{-\mathbf{1}}\end{array}$ & $\begin{array}{c}\mathbf{T}_{\mathbf{a i r}} \\
{ }^{\circ} \mathbf{C}\end{array}$ & $\begin{array}{c}\mathbf{R H} \\
\mathbf{\%}\end{array}$ & $\begin{array}{c}\mathbf{r}_{\mathbf{a h}} \\
\mathbf{s ~ m}^{-\mathbf{1}}\end{array}$ & $\begin{array}{c}\mathbf{T s} \mathbf{R S} \\
{ }^{\circ} \mathbf{C}\end{array}$ & $\begin{array}{c}\mathbf{L A I} \\
\mathbf{m}^{\mathbf{2}} \mathbf{~ m}^{-\mathbf{2}}\end{array}$ & $\begin{array}{c}\mathbf{h}_{\mathbf{c}} \\
\mathbf{m}\end{array}$ & $\begin{array}{c}\mathbf{Z}_{\mathbf{m}} \\
\mathbf{m}\end{array}$ \\
\hline 636.0 & 184.0 & 1.7 & 24.5 & 31.3 & 46.7 & 35.6 & 0.8 & 0.6 & 3.0 \\
\hline 648.0 & 143.0 & 1.7 & 23.4 & 34.7 & 42.5 & 38.0 & 0.9 & 0.7 & 3.0 \\
\hline 657.0 & 240.0 & 1.9 & 24.2 & 32.6 & 43.9 & 39.3 & 0.7 & 0.2 & 2.0 \\
\hline 623.0 & 258.0 & 1.9 & 23.9 & 31.2 & 55.4 & 41.1 & 0.3 & 0.1 & 2.3 \\
\hline 548.0 & 139.0 & 1.5 & 25.6 & 33.1 & 46.8 & 37.6 & 0.8 & 0.6 & 3.0 \\
\hline 578.0 & 107.0 & 1.7 & 25.6 & 30.7 & 41.4 & 38.5 & 0.9 & 0.7 & 3.0 \\
\hline 505.0 & 125.0 & 1.7 & 26.5 & 29.3 & 60.1 & 41.2 & 0.7 & 0.2 & 2.0 \\
\hline 517.0 & 164.0 & 1.9 & 26.1 & 27.6 & 59.0 & 41.5 & 0.3 & 0.1 & 2.3 \\
\hline 656.0 & 212.0 & 2.2 & 24.5 & 32.2 & 54.8 & 40.3 & 0.7 & 0.2 & 2.0 \\
\hline
\end{tabular}


Table A1. Cont.

\begin{tabular}{|c|c|c|c|c|c|c|c|c|c|}
\hline $\begin{array}{c}\mathbf{R}_{\mathbf{n}} \\
\mathbf{W} \mathbf{m}^{-2} \\
\end{array}$ & $\begin{array}{c}\mathbf{G} \\
\mathbf{W ~ m}^{-2} \\
\end{array}$ & $\begin{array}{c}\mathbf{U} \\
\mathrm{m} \mathrm{s}^{-1} \\
\end{array}$ & $\begin{array}{l}\mathbf{T}_{\text {air }} \\
{ }^{\circ} \mathbf{C}\end{array}$ & $\begin{array}{c}\text { RH } \\
\% \\
\end{array}$ & $\begin{array}{r}\mathbf{r}_{\mathrm{ah}} \\
\mathbf{S ~ m}^{-1} \\
\end{array}$ & $\begin{array}{c}\text { Ts_RS } \\
{ }^{\circ} \mathbf{C} \\
\end{array}$ & $\begin{array}{c}\mathbf{L A I} \\
\mathbf{m}^{2} \mathbf{m}^{-2} \\
\end{array}$ & $\begin{array}{c}\mathbf{h}_{\mathbf{c}} \\
\mathbf{m} \\
\end{array}$ & $\begin{array}{c}Z_{\mathbf{m}} \\
\mathbf{m}\end{array}$ \\
\hline 625.0 & 228.0 & 2.3 & 24.2 & 31.2 & 58.4 & 44.1 & 0.3 & 0.1 & 2.3 \\
\hline 600.0 & 292.0 & 2.2 & 24.1 & 30.0 & 65.5 & 42.9 & 0.2 & 0.2 & 1.8 \\
\hline 672.0 & 248.0 & 1.7 & 23.2 & 34.9 & 44.1 & 35.2 & 1.4 & 0.8 & 2.9 \\
\hline 609.0 & 194.0 & 2.9 & 23.0 & 32.1 & 47.1 & 38.3 & 1.0 & 0.6 & 2.9 \\
\hline 537.0 & 138.0 & 5.7 & 24.7 & 58.1 & 18.1 & 34.7 & 1.7 & 0.9 & 3.0 \\
\hline 544.0 & 112.3 & 5.8 & 26.2 & 62.5 & 19.0 & 34.4 & 1.7 & 0.9 & 3.0 \\
\hline 550.0 & 174.7 & 7.0 & 26.5 & 59.2 & 29.3 & 37.5 & 1.1 & 0.2 & 2.0 \\
\hline 522.0 & 187.3 & 7.6 & 26.4 & 58.4 & 32.0 & 37.0 & 1.1 & 0.2 & 2.3 \\
\hline 502.0 & 58.0 & 5.1 & 28.4 & 55.3 & 21.8 & 31.9 & 1.6 & 0.9 & 3.0 \\
\hline 530.0 & 118.0 & 5.5 & 28.9 & 51.9 & 25.6 & 36.4 & 1.1 & 0.2 & 2.0 \\
\hline 486.0 & 140.0 & 6.6 & 28.7 & 51.3 & 27.8 & 36.0 & 1.1 & 0.2 & 2.3 \\
\hline 565.0 & 49.0 & 5.4 & 29.1 & 52.4 & 18.9 & 35.1 & 1.6 & 0.9 & 3.0 \\
\hline 581.0 & 144.0 & 6.0 & 29.6 & 48.5 & 22.6 & 40.0 & 1.1 & 0.2 & 2.0 \\
\hline 543.0 & 146.0 & 7.3 & 29.4 & 47.9 & 25.6 & 39.1 & 1.1 & 0.2 & 2.3 \\
\hline 664.0 & 66.0 & 4.8 & 30.0 & 54.3 & 18.4 & 32.1 & 3.6 & 1.6 & 4.0 \\
\hline 655.0 & 50.0 & 5.2 & 29.9 & 56.9 & 14.9 & 32.3 & 3.4 & 1.5 & 3.9 \\
\hline 648.0 & 87.0 & 5.7 & 30.7 & 50.8 & 27.6 & 43.8 & 1.5 & 0.3 & 2.0 \\
\hline 636.0 & 60.0 & 5.6 & 32.0 & 47.9 & 17.5 & 32.7 & 3.9 & 1.5 & 4.0 \\
\hline 671.0 & 15.0 & 6.1 & 32.0 & 49.4 & 16.7 & 34.2 & 3.3 & 1.4 & 3.9 \\
\hline 610.0 & 103.0 & 6.5 & 33.0 & 44.2 & & 44.4 & 1.6 & 0.3 & 2.0 \\
\hline 603.0 & 45.0 & 5.6 & 31.9 & 49.3 & 20.1 & 33.4 & 3.9 & 1.3 & 4.0 \\
\hline 642.0 & 62.0 & 6.1 & 32.0 & 51.2 & 18.5 & 35.4 & 3.3 & 1.3 & 3.9 \\
\hline 573.0 & 60.0 & 6.6 & 32.9 & 45.6 & 24.8 & 43.3 & 1.6 & 0.3 & 2.0 \\
\hline 637.0 & 66.0 & 4.5 & 29.7 & 55.4 & 21.8 & 31.4 & 3.9 & 1.6 & 4.0 \\
\hline 617.0 & 40.0 & 4.7 & 29.5 & 58.3 & 21.9 & 33.6 & 3.3 & 1.4 & 3.9 \\
\hline 625.0 & 108.0 & 5.5 & 30.3 & 51.9 & 28.7 & 41.7 & 1.6 & 0.3 & 2.0 \\
\hline 684.0 & 65.0 & 5.2 & 30.8 & 51.2 & 17.5 & 31.2 & 4.3 & 1.8 & 3.9 \\
\hline 657.0 & 114.0 & 5.9 & 30.8 & 51.9 & 25.2 & 39.9 & 2.1 & 0.4 & 2.0 \\
\hline 665.0 & 68.0 & 5.4 & 29.4 & 56.7 & 18.9 & 30.8 & 4.7 & 1.9 & 5.0 \\
\hline 647.0 & 75.0 & 5.4 & N/A & $\mathrm{N} / \mathrm{A}$ & N/A & $\mathrm{N} / \mathrm{A}$ & $\mathrm{N} / \mathrm{A}$ & N/A & 2.0 \\
\hline 672.0 & 104.0 & 6.2 & 30.3 & 52.7 & 26.7 & 43.2 & 1.6 & 0.3 & 2.1 \\
\hline 615.0 & 50.0 & 5.6 & 32.1 & 46.8 & 16.1 & 32.8 & 4.3 & 1.8 & 3.9 \\
\hline 611.0 & 69.0 & 6.4 & $\mathrm{~N} / \mathrm{A}$ & N/A & N/A & $\mathrm{N} / \mathrm{A}$ & N/A & N/A & 2.0 \\
\hline 568.0 & 72.0 & 2.2 & 29.4 & 67.2 & 26.3 & 31.6 & 4.5 & 1.8 & 4.0 \\
\hline 530.0 & 27.0 & 2.3 & 28.6 & 71.4 & 28.0 & 32.9 & 3.7 & 1.6 & 3.9 \\
\hline 563.0 & 85.0 & 2.9 & 29.2 & 66.6 & 45.5 & 38.3 & 1.9 & 0.3 & 2.0 \\
\hline 564.0 & 79.0 & 3.3 & 28.7 & 67.8 & 42.9 & 35.7 & 2.6 & 0.4 & 2.3 \\
\hline 620.0 & 97.0 & 3.3 & 31.6 & 70.3 & 19.3 & 30.4 & 5.0 & 2.0 & 4.0 \\
\hline 600.0 & 48.0 & 3.4 & 31.1 & 75.8 & 20.1 & 30.5 & 4.6 & 1.9 & 3.9 \\
\hline 611.0 & 85.0 & 4.2 & 31.0 & 73.8 & 29.7 & 32.5 & 2.8 & 0.5 & 2.0 \\
\hline 600.0 & 91.0 & 4.6 & 30.7 & 74.3 & 29.1 & 31.4 & 3.9 & 0.5 & 2.3 \\
\hline 405.0 & 184.0 & 1.7 & 24.5 & 31.3 & 46.7 & 35.6 & 0.8 & 0.6 & 3.0 \\
\hline 357.0 & 143.0 & 1.7 & 23.4 & 34.7 & 42.5 & 38.0 & 0.9 & 0.7 & 3.0 \\
\hline
\end{tabular}


Table A2. Performance of ANN using combinations of seven independent variables.

\begin{tabular}{|c|c|c|c|c|c|c|c|c|c|c|}
\hline \multirow{2}{*}{$\begin{array}{l}\text { Independent Variables } \\
\text { (uing 7, removing 2) }\end{array}$} & \multirow{2}{*}{$\begin{array}{l}\text { Transfer } \\
\text { Function }\end{array}$} & \multirow{2}{*}{$\begin{array}{l}\text { Train. } \\
\text { Algor. }\end{array}$} & \multicolumn{4}{|c|}{$\begin{array}{c}\text { Correlation Coefficient } \\
\text { (r) }\end{array}$} & \multicolumn{4}{|c|}{$\begin{array}{c}\text { Coefficient of Determination } \\
\qquad\left(\mathbf{R}^{2}\right)\end{array}$} \\
\hline & & & Train. & Valid. & Test. & All & Train. & Valid. & Test. & All \\
\hline $\begin{array}{l}\text { LAI, Ts RS, } \mathrm{r}_{\text {ah }}, \\
\text { RH, } \mathrm{T}_{\text {air }}, \mathrm{U}, \mathrm{R}_{\mathrm{n}}\end{array}$ & Logistic & CGD & 0.97 & 0.95 & 0.92 & 0.95 & 0.94 & 0.85 & 0.69 & 0.89 \\
\hline $\begin{array}{l}\mathrm{h}_{\mathrm{c}}, \mathrm{LAI}, \text { Ts RS, } \\
\mathrm{r}_{\mathrm{ah}}, \mathrm{RH}, \mathrm{T}_{\mathrm{air}}, \mathrm{U}\end{array}$ & Logistic & QP & 0.96 & 0.97 & 0.87 & 0.94 & 0.90 & 0.92 & 0.74 & 0.87 \\
\hline $\begin{array}{l}\mathrm{h}_{\mathrm{c}}, \mathrm{LAI}, \mathrm{Ts} \mathrm{RS}, \\
\mathrm{RH}, \mathrm{T}_{\text {air }}, \mathrm{U}, \mathrm{Rn}\end{array}$ & Logistic & QP & 0.96 & 0.91 & 0.86 & 0.93 & 0.91 & 0.45 & 0.84 & 0.83 \\
\hline $\begin{array}{c}\mathrm{h}_{\mathrm{c}}, \mathrm{LAI}, \mathrm{r}_{\mathrm{ah}}, \mathrm{RH}, \\
\mathrm{T}_{\mathrm{air}}, \mathrm{U}, \mathrm{R}_{\mathrm{n}}\end{array}$ & Logistic & CGD & 0.95 & 0.95 & 0.93 & 0.95 & 0.90 & 0.73 & 0.76 & 0.87 \\
\hline $\begin{array}{l}\mathrm{h}_{\mathrm{c}}, \mathrm{LAI}, \mathrm{Ts} \mathrm{RS}, \\
\mathrm{r}_{\mathrm{ah}}, \mathrm{T}_{\mathrm{air}}, \mathrm{U}, \mathrm{R}_{\mathrm{n}}\end{array}$ & Logistic & QP & 0.97 & 0.94 & 0.92 & 0.95 & 0.94 & 0.81 & 0.69 & 0.90 \\
\hline $\begin{array}{l}\mathrm{h}_{\mathrm{c}}, \mathrm{LAI}, \mathrm{Ts} \mathrm{RS}, \\
\mathrm{RH}, \mathrm{r}_{\mathrm{ah}}, \mathrm{T}_{\text {air }}, \mathrm{R}_{\mathrm{n}}\end{array}$ & Logistic & QP & 0.97 & 0.96 & 0.86 & 0.93 & 0.92 & 0.81 & 0.35 & 0.81 \\
\hline $\begin{array}{l}\mathrm{h}_{\mathrm{c}}, \text { Ts RS, RH, } \\
\mathrm{r}_{\mathrm{ah}}, \mathrm{T}_{\mathrm{air}}, \mathrm{U}, \mathrm{R}_{\mathrm{n}}\end{array}$ & Logistic & CGD & 0.95 & 0.99 & 0.92 & 0.93 & 0.90 & 0.75 & 0.67 & 0.86 \\
\hline $\begin{array}{l}\mathrm{h}_{\mathrm{c}}, \mathrm{LAI}, \mathrm{Ts} \mathrm{RS} \\
\mathrm{RH}, \mathrm{r}_{\mathrm{ah}}, \mathrm{U}, \mathrm{R}_{\mathrm{n}}\end{array}$ & Logistic & CGD & 0.95 & 0.91 & 0.94 & 0.92 & 0.90 & 0.71 & 0.71 & 0.83 \\
\hline $\begin{array}{c}\mathrm{Z}_{\mathrm{m}}, \mathrm{LAI}, \mathrm{Ts} \mathrm{RS} \\
\mathrm{RH}, \mathrm{r}_{\mathrm{ah}}, \mathrm{T}_{\mathrm{air}}, \mathrm{U}\end{array}$ & Logistic & QP & 0.97 & 0.82 & 0.91 & 0.94 & 0.92 & 0.66 & 0.72 & 0.87 \\
\hline $\begin{array}{l}\mathrm{Z}_{\mathrm{m}}, \mathrm{LAI}, \mathrm{Ts} \mathrm{RS} \\
\mathrm{RH}, \mathrm{T}_{\mathrm{air}}, \mathrm{U}, \mathrm{R}_{\mathrm{n}}\end{array}$ & Logistic & CGD & 0.99 & 0.92 & 0.63 & 0.90 & 0.96 & 0.80 & 0.18 & 0.79 \\
\hline $\begin{array}{c}\mathrm{Z}_{\mathrm{m}}, \mathrm{LAI}, \mathrm{r}_{\mathrm{ah}}, \mathrm{RH}, \\
\mathrm{T}_{\mathrm{air}}, \mathrm{U}, \mathrm{R}_{\mathrm{n}} \\
\end{array}$ & Logistic & QP & 0.98 & 0.99 & 0.90 & 0.97 & 0.97 & 0.96 & 0.72 & 0.94 \\
\hline $\begin{array}{c}\mathrm{Z}_{\mathrm{m}}, \mathrm{LAI}, \mathrm{Ts} \mathrm{RS}, \\
\mathrm{r}_{\mathrm{ah}}, \mathrm{T}_{\mathrm{air}}, \mathrm{U}, \mathrm{R}_{\mathrm{n}} \\
\end{array}$ & Logistic & QP & 0.95 & 0.90 & 0.89 & 0.94 & 0.90 & 0.80 & 0.59 & 0.86 \\
\hline $\begin{array}{l}\mathrm{Z}_{\mathrm{m}}, \mathrm{LAI}, \text { Ts RS, } \\
\mathrm{RH}, \mathrm{r}_{\mathrm{ah}}, \mathrm{T}_{\text {air }}, \mathrm{R}_{\mathrm{n}}\end{array}$ & Logistic & Q-N & 0.95 & 0.92 & 0.94 & 0.94 & 0.90 & 0.79 & 0.80 & 0.86 \\
\hline $\begin{array}{l}Z_{\mathrm{m}}, \text { Ts RS, RH, } \\
\mathrm{r}_{\mathrm{ah}}, \mathrm{T}_{\text {air }}, \mathrm{U}, \mathrm{R}_{\mathrm{n}} \\
\end{array}$ & Logistic & QP & 0.97 & 0.97 & 0.96 & 0.96 & 0.93 & 0.90 & 0.86 & 0.92 \\
\hline $\begin{array}{l}\mathrm{Z}_{\mathrm{m}}, \mathrm{LAI}, \mathrm{Ts} \mathrm{RS} \\
\mathrm{RH}, \mathrm{r}_{\mathrm{ah}}, \mathrm{U}, \mathrm{R}_{\mathrm{n}}\end{array}$ & Logistic & $\mathrm{QP}$ & 0.98 & 0.74 & 0.77 & 0.94 & 0.95 & 0.37 & 0.55 & 0.87 \\
\hline $\begin{array}{c}\text { Zm, hc, LAI, } \\
\text { Ts RS, } \mathrm{r}_{\text {ah }}, \mathrm{T}_{\text {air }}, \mathrm{U}\end{array}$ & Logistic & QP & 0.98 & 0.87 & 0.91 & 0.95 & 0.96 & 0.70 & 0.82 & 0.90 \\
\hline $\begin{array}{c}\mathrm{Z}_{\mathrm{m}}, \mathrm{h}_{\mathrm{c}}, \mathrm{LAI}, \mathrm{RH}, \\
\mathrm{r}_{\mathrm{ah}}, \mathrm{T}_{\mathrm{air}}, \mathrm{U} \\
\end{array}$ & Logistic & QP & 0.97 & 0.94 & 0.98 & 0.96 & 0.95 & 0.71 & 0.90 & 0.91 \\
\hline $\begin{array}{c}\mathrm{Z}_{\mathrm{m}}, \mathrm{h}_{\mathrm{c}}, \mathrm{LAI}, \mathrm{Ts} \mathrm{RS}, \\
\mathrm{RH}, \mathrm{T}_{\mathrm{air}}, \mathrm{U}\end{array}$ & Logistic & QP & 0.96 & 0.87 & 0.97 & 0.95 & 0.92 & 0.64 & 0.90 & 0.91 \\
\hline $\begin{array}{c}\mathrm{Z}_{\mathrm{m}}, \mathrm{h}_{\mathrm{c}}, \mathrm{LAI}, \mathrm{Ts} \mathrm{RS} \\
\mathrm{RH}, \mathrm{r}_{\mathrm{ah}}, \mathrm{T}_{\mathrm{air}}\end{array}$ & Logistic & $\mathrm{QP}$ & 0.98 & 0.84 & 0.84 & 0.94 & 0.96 & 0.65 & 0.69 & 0.88 \\
\hline $\begin{array}{c}\mathrm{Z}_{\mathrm{m}}, \mathrm{h}_{\mathrm{c}}, \mathrm{Ts} \mathrm{RS}, \mathrm{RH}, \\
\mathrm{r}_{\mathrm{ah}}, \mathrm{T}_{\mathrm{air}}, \mathrm{U}\end{array}$ & Logistic & Q-N & 0.97 & 0.96 & 0.91 & 0.95 & 0.90 & 0.88 & 0.74 & 0.87 \\
\hline $\begin{array}{c}\mathrm{Z}_{\mathrm{m}}, \mathrm{h}_{\mathrm{c}}, \mathrm{LAI}, \mathrm{Ts} \mathrm{RS}, \\
\mathrm{RH}, \mathrm{r}_{\mathrm{ah}}, \mathrm{U}\end{array}$ & Hyp. Tan. & Q-N & 0.95 & 0.76 & 0.91 & 0.90 & 0.90 & 0.51 & 0.82 & 0.81 \\
\hline
\end{tabular}


Table A2. Cont.

\begin{tabular}{|c|c|c|c|c|c|c|c|c|c|c|}
\hline \multirow{2}{*}{$\begin{array}{c}\text { Independent Variables } \\
\text { (uing 7, removing 2) }\end{array}$} & $\begin{array}{c}\text { Transfer } \\
\text { Function }\end{array}$ & \multirow{2}{*}{ Train. } & \multicolumn{3}{|c|}{ Correlation Coefficient } & \multicolumn{3}{|c|}{ Coefficient of Determination } \\
\cline { 4 - 10 }$\left(\mathbf{R}^{2}\right)$
\end{tabular}

(C) 2011 by the authors; licensee MDPI, Basel, Switzerland. This article is an open access article distributed under the terms and conditions of the Creative Commons Attribution license (http://creativecommons.org/licenses/by/3.0/). 